\title{
ASSESSMENT OF POTENTIAL DRUG INTERACTIONS AMONG HOSPITALIZED PATIENTS AT THE CARDIAC AND PULMONARY DEPARTMENTS IN TERTIARY CARE HOSPITALS
}

\author{
KAMESWARAN RAMALINGAM ${ }^{1 *}$, SHANMUGA SUNDARAM RAJAGOPAL ${ }^{2}$, KRISHNAVENI KANDASAMY ${ }^{1}$, \\ KARTHIKEYAN KRISHNAN ${ }^{1}$
}

${ }^{1}$ Department of Pharmacy Practice, Faculty of Pharmacy, Pacific Academy of Higher Education and Research University, Udaipur, Rajasthan, India. ${ }^{2}$ Department of Pharmacology, J.K.K. Nattraja College of Pharmacy, Kumarapalayam, Tamil Nadu, India. Email: kamesjohashwanth@gmail.com

Received: 03 February 2018, Revised and Accepted: 09 April 2018

\begin{abstract}
Objective: The aim of this study was to assess the potential drug interactions among hospitalized patients in cardiac and pulmonary wards in three tertiary care hospitals.

Methods: A prospective, observational study was carried out for 12 months. A sample of 1150 patients were assessed for potential drug-drug interactions (pDDIs) using Micromedex ${ }^{\circledR}-2.7$ and Drugs.com.

Results: A total of 1150 patients were analyzed, and it was found that 685 were cardiac and 465 were pulmonary patients. The study identified $524(76.49 \%)$ cardiac patients and 345 (74.19\%) pulmonary patients, with pDDIs higher in male cardiac (298 [56.87\%]) and male pulmonary (199 [57.68\%]) patients, compared to females. Incidences of pDDIs were found to be higher in the age group of 60-70 years in cardiac (193 [36.83\%]) and pulmonary (146 [42.31\%]) patients and incidences of interactions based on duration of 4-6 days' hospital stays in cardiac were 380 (72.53\%) and $215(62.31 \%)$ in pulmonary patients, respectively. Moreover, $51.90 \%$ of cardiac patients and $56.52 \%$ of pulmonary patients were found to be prescribed with more number of drugs (cardiac 7 drugs and pulmonary 5-6 drugs) causing higher incidences of pDDIs. Some of the most common drug interacting pair was aspirin and clopidogrel combination observed in 245 cardiac patients, whereas in the pulmonary department, it was ranitidine-theophylline combination with a frequency of 195 pDDIs. Drug-food interactions were found with atorvastatin-citrus fruits in cardiac and theophylline-caffeine in pulmonary patients. The most common drug-disease interaction was found to be isosorbide dinitrate-myocardial infarction in cardiac and diazepam-COPD in pulmonary, respectively.
\end{abstract}

Conclusion: Pharmacists must take responsibility in the monitoring of drug interactions and notifying the physician and patient about potential problems. With their detailed knowledge of drugs, pharmacists have the ability to relate unexpected symptoms experienced by patients to possible adverse effects of their drug therapy.

Keywords: Cardiac, Drug-drug interactions, Pulmonary, Aspirin, Clopidogrel, ISDN-MI.

(C) 2018 The Authors. Published by Innovare Academic Sciences Pvt Ltd. This is an open access article under the CC BY license (http://creativecommons. org/licenses/by/4. 0/) DOI: http://dx.doi.org/10.22159/ajpcr.2018.v11i5.25081

\section{INTRODUCTION}

A drug interaction occurs when a patient's response to a drug is modified by food, nutritional supplements, formulation excipients, environmental factors, other drugs, or disease. Drug interactions are a major area of concern these days. The study of drug-drug, fooddrug, and disease-drug interactions and of genetic factors affecting pharmacokinetics and pharmacodynamics is expected to improve drug safety and will enable individualized drug therapy. Drug-drug interactions are said to account for a number of severe adverse drug reaction, resulting in hospitalizations and emergency department visits. It is estimated that, in 2011, DDI contributed to about $56.4 \%$ of all ADR [1]. Furthermore, ADR due to DDI accounts for about $2.8 \%$ hospital admission every year [2]. Many adverse events can be prevented by identifying potential drug interactions (pDIs). However, certain conditions such as multiple disorders, chronic diseases, and polypharmacy may increase the risk of potential drugdrug interaction. In the elderly, concomitant use of several drugs (polypharmacy) is very common and carries a high risk of both drugdrug interaction and drug-disease. A study in 2010 reported that $558(26.5 \%)$ of elder people taking medicines were exposed to at least one DDI [3]. It was reported in 2011 that 164 (75.9\%) patients taking 7 or more drugs were having at least one potential drug-drug interactions (pDDIs) while $76(73.8 \%)$ patients with a hospital stay of seven or more were at risk of DDIs [4]. Patients with cardiovascular disorders are even at higher risk of DDI due to the number and types of drug they receive and the influence of heart disease on drug metabolism. A prospective study conducted in one of the teaching hospitals in India in 2011 indicated that the incidence of pDI among cardiac drugs in hospitalized patients is $30.67 \%$ [5]. A cross-sectional study conducted in the Pulmonology Department, Ayub Teaching Hospital, Pakistan, in 2011 showed that among 558 pDDIs, most were of moderate $(53.6 \%)$ or major $(34 \%)$, good $(74.2 \%)$ or fair $(16.3 \%)$, and delayed onset (70\%) [4].

Diet and lifestyle can sometimes have a significant impact on drugs. These may occur of accidental misuse or due to lack of knowledge about the active ingredients involved in the relevant substances. Interactions between food and drugs may inadvertently reduce or increase the drug effect. Major side effects of some diet (food) on drugs include alteration in absorption of fatty, high protein, and fiber diets. Sixteen cohort and case-control studies reported an elevated risk of hospitalization in patients who were exposed to pDDIs [6]. Studying the drug-drug interactions, food-drug interactions, and disease-drug interactions is essential for the management of drug therapy. The exhaustive literature review revealed that studies have been conducted on the pDDIs in the departments. Hence, we carry out a study to assess the prevalence of drug-drug interactions, food-drug interactions, and disease-drug interactions. 


\section{METHODS}

The research was conducted in three tertiary care hospitals, in Erode, for 12 months at the hospitalized cardiac and pulmonary patients. 1150 patients were taken in for the study, of which 685 were cardiac, and 465 were pulmonary patients. Exclusion criteria included out patients, patients $<18$ years of age, medical disability, and patients who are on Ayurveda, Siddha, or other alternative system of medicine. Consent was obtained from hospital authority and hospitalized patients. The data were collected from case sheets of hospitalized patients and direct patient interview from cardiac and pulmonary departments. Demographic information (age and sex), length of hospital stay, main diagnosis, number of drugs, and details of comorbidities were obtained from the clinical records. All medications that were prescribed, including routine and pro re nata (means as required) medications, were screened for pDDIs. pDDIs were detected using the Drug Interactions Checker within Micromedex ${ }^{\circledR}-2.7$ and www.drugs. com. The detected DDIs were classified as major, moderate, and minor, relying on their severity of clinical significance and cross-over checked manually for the presence of enough published medical evidence for the recognized interacting marketers. Primarily, based on the profile of medicines prescribed, the DDIs had been recognized and classified in step with the Micromedex ${ }^{\circledR}-2.7$ and www.drugs.com. In line with the types, pDDIs have been categorized as: Pharmacokinetics - absorption, distribution, metabolism, and excretion and pharmacodynamics - antagonism, synergism, and additive. In line with severity, pDDIs were labeled as: Major - the consequences are probably life threatening or capable of inflicting permanent harm; moderate - the outcomes may also cause deterioration in patients' scientific fame and additional treatment or extension of hospital stay; and minor- the consequences are typically moderate. The effects can be bothersome or unnoticeable, but need to now, not considerably affect the healing outcome. Frequencies expressed as possibilities were used to summarize sex, diagnosis, number of medication disbursed frequency of pDDIs, the drugs concerned with the pDDIs, period of hospital stay and types, and severity of pDDIs.

\section{RESULTS}

A total of 1150 patients were admitted at the department of cardiac and pulmonary during the study period. Among these, 685 were cardiac and 465 were pulmonary patients. Of 685 cardiac patients, $524(76.49 \%)$ had found to be pDDIs, 856 pDDIs were found at 524 cardiac patients, and 675 pDDIs were found at 465 pulmonary patients. It was found that patients were confirmed with minimum one or two pDDIs in both cardiac and pulmonary patients. Of which, 298 (56.87\%) cardiac males and 199 (57.68\%) pulmonary males were found to be higher pDDIs, compared to females. Incidences of pDDIs were found to be higher in the age group of $60-70$ years in cardiac (193 [36.83\%]) and pulmonary (146 [42.31\%]) patients and incidences of interactions based on duration of (4-6 days) hospital stay were 380 (72.53\%) and $215(62.31 \%)$ in cardiac and pulmonary patients, respectively. $51.90 \%$ of patients prescribed with more than seven drugs in cardiac and $56.52 \%$ of patients prescribed with between five and six drugs in pulmonary patients were found to have developed a higher number of pDDIs (Table 1).

On average, each patient had one or two coded diagnosis in which hypertension was the most common condition 165 (31.48\%), followed by angina with diabetes mellitus $111(21.18 \%)$ in cardiac patients and asthma 92 (26.66\%), followed by the asthma with LRTI 75 (21.73\%) in pulmonary patients (Tables 2-11).

\section{DISCUSSION}

DIs are a major area of concern these days for the effective management of patient illness. It may create a considerable health hazard to the patients when the risk-benefit ratio of combining interacting drugs is not accurately estimated. It has already been approximated that the effect of drug interactions can range from any minor morbidity to fatal consequences. The study of drug-drug, drug-food, and drugdisease interactions and genetic factors affecting pharmacokinetics and pharmacodynamics is expected to improve drug safety and will enable individualized drug therapy.

The present study identified a total of 1150 patients admitted at the department of cardiac and pulmonary, during the study period. Among these, 685 were cardiac and 465 were pulmonary patients. Of 685 cardiac patients, 524 (76.49\%) had found to be pDDIs, 856 pDDIs were found in 524 cardiac patients (Fig. 1). 675 pDDIs were found in 465 pulmonary patients. Out of which 298 (56.87\%) cardiac male, and $199(57.68 \%)$ pulmonary male were found to be higher pDDIs, compared to females (Table 1), similar to the study conducted by Mukesh et al, where male patients $(67 \%)$ had a high frequency of cardiovascular incidence as compared to female patients (33\%) [7]. Another study conducted by Murtaza et al. also reported that male patients had a higher cardiology (50.94\%), pulmonary (56.41\%), and pDDIs possible when compared to females in the present study may be the primary reason [8]. Another reason possibly will be the greater risk of cardiovascular and pulmonary disorders among male gender in comparison to female, and hence, there is a need for multiple drugs which ultimately result in drug interactions.

The study showed that the majority of the incidences of pDDIs were found to be higher in the age group of 60-70 years in 193 (36.85\%) cardiac and $146(42.33 \%)$ pulmonary patients (Table 1). A study conducted by Chelkeba et al. reported an age group of 59-69 years [9], whereas a study conducted by Fita $e t$ al. reported that the majority of patients ages were between 70 and 74 years [10]. Older people were at high risk of developing an ADR due to pDDIs for several reasons. They are likely to have higher commodities and thus take several prescriptions and over the counter drugs. As people get older, the liver loses the ability to metabolize drugs. Furthermore, older people are more than twice as susceptible to ADRs as younger people. As people age, the amount of water in the body decreases and the amount of fat tissue relative to water increases. Furthermore, as people age, the kidneys are less able to excrete drugs into the urine, and the liver is less able to metabolize many drugs.

The study revealed $72.53 \%$ of cardiac and $62.31 \%$ of pulmonary cases, that the number of hospital stay was between 4-6 days (Table 1). Lubinga et al, conducted a study which showed that the majority of the cases the number of hospital stay were less than 6 days [11]. The likelihood of getting the multiple drugs increases with the increased length of hospital stay which in turn will increase the likelihood of pDDIs.

In our study, $51.90 \%$ of patients were prescribed with more than seven drugs in the cardiology department (Table 1). The study conducted by de Andrade et al. revealed that $40.6 \%$ of cases were prescribed between 13 and 16 drugs [12]. $56.52 \%$ of patients prescribed with between 5 and 6 drugs in the pulmonology department. A study conducted by Ismail et al. showed that $54 \%$ of cases had more than seven drugs prescribed [4]. Mannesse et al. reported the concurrent use of three or more drugs increased the risk of ADE's by 9.8 times [13]. More the medications that are prescribed, the more the possibility of irrational polypharmacy. A study conducted by Doan et al. determined the probability of potent cytochrome P450 (CYP 450) interactions in older hospitalized people taking more than five concurrent medicines [14]. Potential drug-drug interactions were present in $80 \%$ of people taking more than five concurrent medicines. People taking five concurrent medicines had a $50 \%$ probability of at least one drug interaction, each additional medicine adds a $12 \%$ increase in the risk of drug interactions.

The most common interacting pair at the cardiac department was found to be aspirin and clopidogrel, causing major pharmacodynamic interaction, with a frequency of 245 (Table 3). The finding of the study is similar to the study conducted by Murtaza et al., in which the most common interacting pair was identified as aspirin-clopidogrel followed by clopidogrel-fondaparinux [8]. Another study conducted by Yanti et al. 
Table 1: Demographic profile of cardiac and pulmonary patients

\begin{tabular}{lll}
\hline Parameter & Cardiac total number of patients $\mathbf{n = 5 2 4}(\%)$ & Pulmonary total number of patients $\mathbf{n = 3 4 5}(\mathbf{\%})$ \\
\hline $\begin{array}{l}\text { Gender-wise distribution } \\
\quad \text { Male }\end{array}$ & $298(56.87)$ & $199(57.68)$ \\
$\quad$ Female & $226(43.13)$ & $146(42.32)$ \\
Age-wise distribution & $21(4.00)$ & \\
$\quad 18-30$ & $69(13.17)$ & $33(9.56)$ \\
$31-45$ & $164(31.29)$ & $35(10.14)$ \\
$46-59$ & $193(36.85)$ & $86(24.93)$ \\
$60-70$ & $77(14.69)$ & $146(42.33)$ \\
Above 70 & $83(15.83)$ & $45(13.04)$ \\
Number of hospital stay (in days) & $380(72.53)$ & $85(24.63)$ \\
$\quad<3$ & $61(11.64)$ & $215(62.31)$ \\
$4-6$ & & $45(13.06)$ \\
$>7$ & $94(17.93 \%)$ & \\
Number of prescribed drugs per day & $158(30.15)$ & $54(15.65)$ \\
$<4$ & $272(51.90)$ & $195(56.52)$ \\
$5-6$ & & $96(27.82)$ \\
$>7$ &
\end{tabular}

Table 2: Types of diseases in each department

\begin{tabular}{|c|c|c|c|}
\hline \multicolumn{2}{|l|}{ Cardiology $(n=524)$} & \multicolumn{2}{|l|}{ Pulmonary $(n=345)$} \\
\hline Type of diseases & Number of patients & Type of diseases & Number of patients \\
\hline Myocardial infarction & $87(16.60)$ & Asthma & $92(26.66)$ \\
\hline Angina+diabetes mellitus & $111(21.18)$ & Asthma+LRTI & $75(21.73)$ \\
\hline Hypertension & $165(31.48)$ & Pneumonia & $48(13.91)$ \\
\hline Ischemic heart disease & $46(08.77)$ & Pneumonia+bronchitis & $34(09.85)$ \\
\hline Coronary artery disease & $34(06.48)$ & Bronchitis & $47(13.62)$ \\
\hline
\end{tabular}

LRTI: Lower respiratory tract infection, COPD: Chronic obstructive pulmonary disease

Table 3: Highest potential drug-drug interaction combinations in cardiology

\begin{tabular}{|c|c|c|c|}
\hline $\begin{array}{l}\text { pDDI } \\
\text { combination }\end{array}$ & Type & Severity & $\begin{array}{l}\text { Frequency } \\
n=856(\%)\end{array}$ \\
\hline $\begin{array}{l}\text { T. aspirin+ } \\
\text { T. clopidogrel }\end{array}$ & PD & Major & 245 (28.62) \\
\hline $\begin{array}{l}\text { T. aspirin+ } \\
\text { T. enalapril }\end{array}$ & PD & Moderate & $69(8.06)$ \\
\hline $\begin{array}{l}\text { T. atorvastatin+ } \\
\text { T. clopidogrel }\end{array}$ & PK & Moderate & 78 (9.11) \\
\hline $\begin{array}{l}\text { T. aspirin+ } \\
\text { T. atenolol }\end{array}$ & PD & Moderate & $25(2.92)$ \\
\hline $\begin{array}{l}\text { T. clopidogrel+ } \\
\text { T. amlodipine }\end{array}$ & $\mathrm{PK}$ & Moderate & $80(9.34)$ \\
\hline $\begin{array}{l}\text { T. atenolol+ } \\
\text { T. metformin }\end{array}$ & $\mathrm{PK}$ & Major & $25(2.92)$ \\
\hline $\begin{array}{l}\text { T. spironolactone+ } \\
\text { T. enalapril }\end{array}$ & PD & Moderate & $18(2.10)$ \\
\hline $\begin{array}{l}\text { T. enalapril+ } \\
\text { T. metformin }\end{array}$ & Unknown & Major & $15(1.75)$ \\
\hline $\begin{array}{l}\text { T. enalapril+ } \\
\text { T. furosemide }\end{array}$ & PD & Moderate & $12(1.40)$ \\
\hline $\begin{array}{l}\text { T. aspirin+ } \\
\text { T. spironolactone }\end{array}$ & PD & Major & $41(4.78)$ \\
\hline
\end{tabular}

PD: Pharmacodynamics, PK: Pharmacokinetics, pDDIs: Potential drug-drug interactions

observed a combination of diltiazem-amlodipine and spironolactonepotassium chloride [5]. Diltiazem may increase the serum amlodipine level by affecting CYP3A4, while the combination of spironolactone and potassium chloride will potentially increase potassium levels. The most common interacting pair at a pulmonology department in the present study was ranitidine-theophylline, which is a minor pharmacokinetic interaction, with a frequency of 195 (Table 4). Another study conducted

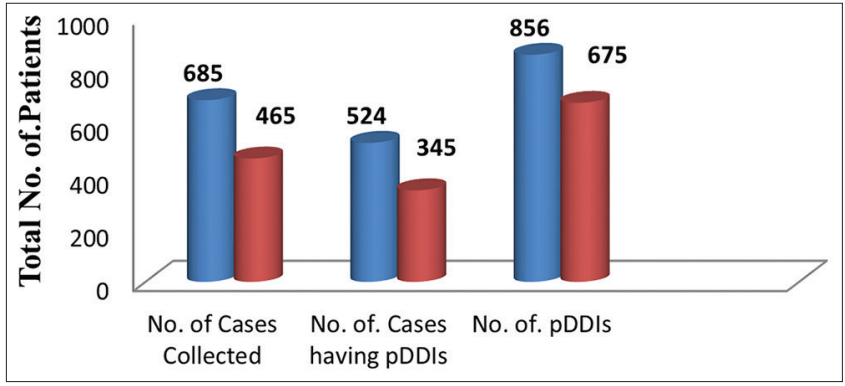

Fig 1: Distribution of drug interactions in various departments

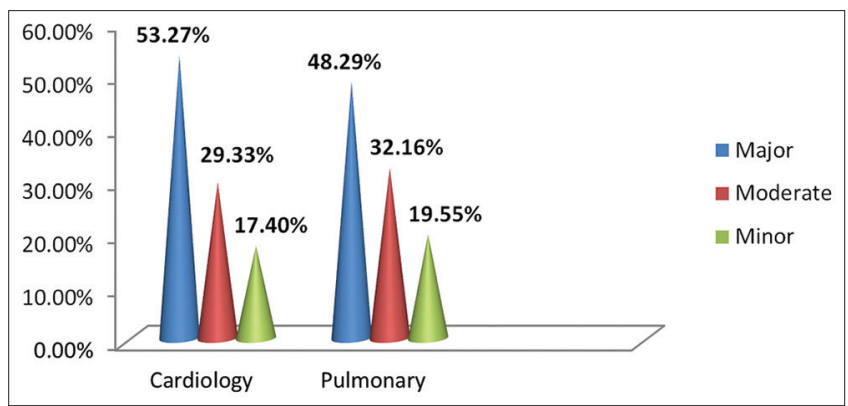

Fig 2: Prevalence of potential drug-drug interactions

by Ismail et al. showed dexamethasone-rifampicin as the most common interacting pair [4]. Rifampin can reduce the pharmacological effects of corticosteroids (dexamethasone and prednisolone). It is suggested to monitor corticosteroid effects and increase the dose if necessary. A dose reduction may be necessary if rifampin is discontinued. 
Table 4: Interactive effect, M.O.A, clinical management of common potential drug-drug interactions in cardiology

\begin{tabular}{|c|c|c|c|}
\hline pDDI combination & Mechanism of action & Interactive effect & Clinical management \\
\hline T. aspirin+T. clopidogrel & Increased risk of bleeding & Additive effect & $\begin{array}{l}\text { Monitor for blood counts if coadministration is } \\
\text { needed }\end{array}$ \\
\hline T. aspirin $+\mathrm{T}$. enalapril & $\begin{array}{l}\text { Decreased effectiveness of } \\
\text { enalapril }\end{array}$ & Antagonistic effect & Weigh benefit and risk \\
\hline T. atorvastatin $+\mathrm{T}$. clopidogrel & $\begin{array}{l}\text { Decreased formation of } \\
\text { the clopidogrel active } \\
\text { metabolite resulting in } \\
\text { higher on-treatment platelet } \\
\text { reactivity }\end{array}$ & Metabolism & $\begin{array}{l}\text { Discontinue the statin and substitute a statin } \\
\text { that is not metabolized by CYP3A4 (i.e, } \\
\text { pravastatin or rosuvastatin) }\end{array}$ \\
\hline T. aspirin $+\mathrm{T}$. atenolol & $\begin{array}{l}\text { Decreased antihypertensive } \\
\text { effect }\end{array}$ & Antagonistic effect & $\begin{array}{l}\text { Monitor for the patient's blood counts and dose } \\
\text { adjustment for beta blockers if necessary }\end{array}$ \\
\hline T. clopidogrel+T. amlodipine & $\begin{array}{l}\text { Decreased antiplatelet } \\
\text { effect and increased risk of } \\
\text { thrombotic events }\end{array}$ & $\begin{array}{l}\text { Inhibit } \\
\text { CYP3A (metabolism) }\end{array}$ & $\begin{array}{l}\text { The addition of cilostazol may reduce the } \\
\text { potential harmful interactions }\end{array}$ \\
\hline T. atenolol+T. metformin & $\begin{array}{l}\text { Result in hypoglycemia or } \\
\text { hyperglycemia }\end{array}$ & $\begin{array}{l}\text { Altered glucose } \\
\text { metabolism }\end{array}$ & Monitor for patient's glucose level \\
\hline T. enalapril+T. metformin & $\begin{array}{l}\text { Increased risk of } \\
\text { hypoglycemia }\end{array}$ & Unknown mechanism & Avoid concurrent use \\
\hline T. enalapril+T. furosemide & $\begin{array}{l}\text { Result in postural } \\
\text { hypotension }\end{array}$ & Synergistic effect & Discontinue the diuretic 2 or 3 days before ACEI \\
\hline T. aspirin+T. spironolactone & $\begin{array}{l}\text { Result in hyperkalemia, or } \\
\text { possible nephrotoxicity }\end{array}$ & Additive effect & $\begin{array}{l}\text { Avoid aspirin doses of }>650 \mathrm{mg} \text { daily in adults } \\
\text { receiving spironolactone }\end{array}$ \\
\hline
\end{tabular}

pDDIs: Potential drug-drug interactions

Table 5: Highest potential drug-drug interaction combinations in pulmonary

\begin{tabular}{llll}
\hline pDDI combination & Type & Severity & $\begin{array}{l}\text { Frequency } \\
\mathbf{n = 6 7 5}(\mathbf{6})\end{array}$ \\
\hline $\begin{array}{l}\text { Injection } \\
\text { ranitidine+Injection } \\
\text { theophylline }\end{array}$ & PK & Minor & $195(28.88)$ \\
$\begin{array}{l}\text { Injection } \\
\text { furosemide+Injection } \\
\text { hydrocortisone }\end{array}$ & PD & Moderate & $68(10.07)$ \\
$\begin{array}{l}\text { Injection } \\
\text { ciprofloxacin+Injection } \\
\text { theophylline }\end{array}$ & PK & Major & $82(12.14)$ \\
$\begin{array}{l}\text { C. omeprazole+ } \\
\text { T. clopidogrel }\end{array}$ & PK & Major & $55(8.14)$ \\
$\begin{array}{l}\text { Injection } \\
\text { furosemide+Injection } \\
\text { theophylline }\end{array}$ & Unknown & Minor & $86(12.74)$ \\
\hline $\begin{array}{l}\text { pDDIs: Potential drug-drug interactions } \\
\text { nd }\end{array}$ & &
\end{tabular}

The prevalence of pDDIs in the cardiac department in our study was 53.27\% (Table 7 and Fig. 2). A similar study performed by Ismail $e t$ al. showed an overall 77.5\% PDDI prevalence rate among randomly selected cardiac patients [4]. A study conducted by Murtaza et al. in the department of cardiology showed that the prevalence rate of PDDIs was $91.6 \%$ among the studied cardiac patients [8]. The prevalence of pDDIs in the pulmonary department in our study was $48.29 \%$ (Table 7). A similar study that was conducted by Ismail et al. reported an overall prevalence of $45 \%$ [4].

In our study, the prevalence of pDDIs was higher in major severity accounted at $456(53.27 \%)$ cardiology and $326(48.29 \%)$ pulmonary patients. Fokter et al. reported pDDIs of major severity in $13 \%$ of patients [15] and Ismail et al. in $24.25 \%$ of patients [3]. Prevalence of pDDIs of moderate severity was $30.94 \%$. Patel et al. reported moderate severity in $60.3 \%$ of patients [5]. This study contrasts the other studies which report moderate severity. These potential DDIs suggest that there is a need for modification or alteration of therapy such as dosage adjustment. To prevent these DDIs, healthcare providers should have adequate information about DDIs not

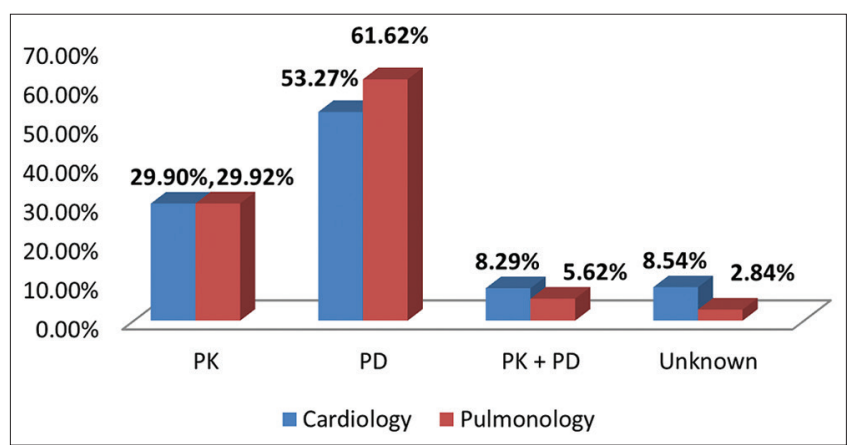

Fig 3: Classification of types of potential drug-drug interactions

only through drug information center, which can provide evidencebased information to health-care professionals, but also through encouraging the empowerment of clinical pharmacists that can provide an evidence-based approach to drugs and thereby prevent drug therapy problems of which DDIs is one.

Of 524 cardiac cases, there were 82 interacting pairs identified during the study. Among 856 pDDIs, 256 (29.90\%) were due to pharmacokinetic interactions, and 456 (53.27\%) were pharmacodynamic interactions. $71(8.29 \%)$ show both mechanisms and $73(8.54 \%)$ were due to unknown mechanisms. Among 256 pharmacokinetic drug interactions, $39(15.23 \%)$ were due to absorption, $41(16.01 \%)$ were due to distribution, 141 (55.07\%) were due to metabolism, and 35 (13.67\%) were due to excretion. Among 456 pharmacodynamic interactions, $28(6.14 \%)$ were synergistic, $115(25.21 \%)$ were antagonistic, $294(64.47 \%)$ were added, and $19(4.18 \%)$ with both additive and antagonistic effects. According to Chavda et al., among 423 pDDIs, $50.83 \%$ were pharmacodynamic drug interactions, $38.53 \%$ were pharmacokinetics, and $10.64 \%$ were both kinds of mechanisms (Fig. 3) [16]. From 163 pharmacokinetics pDDIs, 45.41\% were altered the absorption, $28.99 \%$ were altered the metabolism, and $25.60 \%$ were altered the excretion. Of the 215 pharmacodynamic pDDIs, $67.44 \%$ were synergistic, $30.70 \%$ antagonistic, and $1.86 \%$ unknown in nature. The reason for the majority being pharmacodynamic interaction is that these types of interactions derive from modification of the action of one drug at the target site by another drug, independent of a change in its 
Table 6: Interactive effect, M.O.A, clinical management of common potential drug-drug interactions in pulmonology

\begin{tabular}{|c|c|c|c|}
\hline pDDI combination & Mechanism of action & Interactive effect & Clinical management \\
\hline $\begin{array}{l}\text { Injection ranitidine+Injection } \\
\text { theophylline }\end{array}$ & $\begin{array}{l}\text { Theophylline toxicity (nausea, vomiting, } \\
\text { palpitations, seizures) }\end{array}$ & Decrease metabolism & $\begin{array}{l}\text { Dosing adjustments of } \\
\text { theophylline may be } \\
\text { necessary }\end{array}$ \\
\hline $\begin{array}{l}\text { Injection furosemide+Injection } \\
\text { hydrocortisone }\end{array}$ & Result in hypokalemia & $\begin{array}{l}\text { Antagonistic effect; additive } \\
\text { effect }\end{array}$ & $\begin{array}{l}\text { Potassium balance should } \\
\text { be carefully monitored } \\
\text { during concomitant } \\
\text { therapy }\end{array}$ \\
\hline C. omeprazole+T. clopidogrel & $\begin{array}{l}\text { Reduction in clinical efficacy of } \\
\text { clopidogrel and increased risk for } \\
\text { thrombosis }\end{array}$ & Inhibit metabolism & $\begin{array}{l}\text { Avoid concomitant } \\
\text { use of clopidogrel } \\
\text { and omeprazole. } \\
\text { Rabeprazole (given } 4 \\
\text { hours after clopidogrel), } \\
\text { pantoprazole, and } \\
\text { dexlansoprazole have less } \\
\text { effect on the antiplatelet } \\
\text { activity of clopidogrel }\end{array}$ \\
\hline $\begin{array}{l}\text { Injection furosemide+Injection } \\
\text { theophylline }\end{array}$ & Altered theophylline concentrations & Unknown & $\begin{array}{l}\text { Dosing adjustments of } \\
\text { theophylline may be } \\
\text { necessary }\end{array}$ \\
\hline
\end{tabular}

pDDIs: Potential drug-drug interactions

Table 7: Prevalence of pDDIs

\begin{tabular}{lll}
\hline Type of prevalence & Cardiology & Pulmonary \\
\hline Severity of pDDIs & $\begin{array}{l}\text { Frequency } \\
\mathrm{n}=856(\%)\end{array}$ & Frequency $\mathrm{n}=675(\%)$ \\
& $456(53.27)$ & $326(48.29)$ \\
Major & $251(29.33)$ & $217(32.16)$ \\
Moderate & $149(17.40)$ & $132(19.55)$ \\
Minor &
\end{tabular}

pDDIs: Potential drug-drug interactions

concentration. This may result in enhanced response (synergism), an attenuated response (antagonism), or an abnormal response.

Of 345 pulmonary cases, 68 interacting pairs were identified during the study. Among 675 pDDIs, 202 (29.92\%) were pharmacokinetic interactions, $416(61.62 \%)$ were pharmacodynamic interactions. $38(5.62 \%)$ show both mechanisms, and 19 (2.84\%) were unknown mechanism. Among 202 pharmacokinetic drug interactions in pulmonary department, 114 (56.43\%) were due to metabolism. Among 416 pharmacodynamic interactions, 276 (66.34\%) were synergistic, identified to a study reported by Chavda et al, where $67.44 \%$ were synergistic followed by $30.7 \%$ antagonistic [16]. From pDDIs detected in the study by Chavda et al., the majority were of pharmacodynamic (58.83\%) in nature, followed by pharmacokinetics (38.53\%) interactions [16]. These findings are in contrast to the study reported by Vonbach et al. [17] and Aparasu et al., wherein, it was reported that $76 \%$ of pharmacokinetics and $22 \%$ of pharmacodynamic interactions (Fig. 3) [18].

Diet and lifestyle can sometimes have a significant impact on drugs. These may occur out of accidental misuse or due to lack of knowledge about the active ingredients involved in the relevant substances. Interactions between food and drugs may inadvertently reduce or increase the drug effect. Major side effects of some diet (food) on drugs include alteration in the absorption of fatty, high protein, and fiber diets.

According to this study, a total of 1150 patients were studied at cardiology and pulmonary departments. Among this, 685 were cardiac and 465 were pulmonary patients. Of 685 cardiac patients, $290(42.33 \%)$ were found to be drug-food interactions (DFIs). 457
pDFIs were found in 290 cardiac patients. 278 pDFIs were found in 165 pulmonary patients. The most common pDFIs were between atorvastatin and citrus fruits, in cardiac patients, with a frequency of 144 (Table 8), which may cause decreased first-pass metabolism and increased bioavailability of atorvastatin that further results in muscle breakdown, liver damage, digestive problems, increased blood sugar, and neurological side effects. The reason for these interactions is due to furanocoumarins. The interaction between citrus fruits and medications poses dangers only if a drug is taken orally because the interaction occurs in the digestive tract. The second most common interaction was banana interacting with the ACE inhibitors, with a frequency of 83, to cause hyperkalemia [19]. Bananas are high in potassium. Too much potassium can cause an irregular heartbeat and heart palpitations.

Of 278 pDFIs, 165 were found in pulmonary patients. The most common pDFIs were found between theophylline and caffeine (coffee/tea) with a frequency of $120(43.16 \%)$ (Table 9), followed by theophyllineprotein-rich foods (fish, milk, and egg) with a frequency of 55 (19.78\%). Tse et al. conducted a study that suggested that interactions between theophylline and caffeine may be attributed to changes in drug distribution and drug elimination characteristics [20].

A total of 1150 patients were studied at cardiology and pulmonary departments. Among these, 685 were cardiac and 465 were pulmonary patients. Of 685 cardiac patients, 175 (42.06\%) had found to be pDDIs. 289 pDDIs were found in 175 cardiac patients. 138 pDDIs were in $93(22.35 \%)$ pulmonary patients. The most common drug-disease interaction was found between ISDN and MI (Table 10). The interaction may result in systemic hypotension and tachycardia. It may also exacerbate myocardial ischemia. The second common drug-disease interaction was found to be furosemide with DM. This interaction may result in latent diabetes which may become overt: Insulin requirements in established diabetes may increase. Therefore, it is advisable to stop furosemide before a glucose tolerance test. The most common pDDIs found between diazepam and COPD in pulmonary patients (Table 11). This interaction may result in risk of respiratory depression. Dimitriadis et al. conducted a study which reported that the effects of furosemide may contribute to the decrease in glucose utilization [21]. 
Table 8: Distribution of potential DFIs in cardiology

\begin{tabular}{lllll}
\hline Drug-food & Interactive effect & Type of DFI & Severity & Frequency n=457 (\%) \\
\hline T. atorvastatin with citrus fruits & $\begin{array}{l}\text { Decreased first-pass metabolism and increased } \\
\text { bioavailability }\end{array}$ & PK & Moderate & $144(31.50)$ \\
T. enalapril with banana & $\begin{array}{l}\text { Hyperkalemia } \\
\text { Decrease the mean peak plasma concentration of } \\
\text { T. atenolol with orange juice }\end{array}$ & $\begin{array}{l}\text { Unknown } \\
\text { atenolol; excretion of drugs in urine decreased }\end{array}$ & Moderate & $47(10.28)$ \\
T. diazepam with tea/coffee & $\begin{array}{l}\text { Antagonistic effect. Caffeine generally antagonized } \\
\text { the diazepam-induced ratings of sedation and }\end{array}$ & PD & Moderate & $79(17.28)$ \\
& impairment of psychomortor performance & & 83 (18.16) \\
T. Bisacodyl with milk & Increase the risk of stomach upset and nausea & Unknown & Minor & $91(19.91)$ \\
T. paracetamol with cabbage & Decrease effectiveness of the drug & PK & Moderate & $38(8.31)$ \\
\hline
\end{tabular}

Table 9: Distribution of potential DFIs in pulmonology

\begin{tabular}{|c|c|c|c|c|}
\hline Drug-food & Interactive effect & Type of DDI & Severity & Frequency $n=278(\%)$ \\
\hline T. theophylline with coffee/tea (caffeine) & $\begin{array}{l}\text { Increased plasma concentration by } \\
\text { inhibiting metabolism }\end{array}$ & PK & Moderate & $120(43.16)$ \\
\hline $\begin{array}{l}\text { T. theophylline with protein-rich } \\
\text { foods (fish, milk, egg, meat) }\end{array}$ & Increased clearance of the drug & Unknown & Moderate & $55(19.78)$ \\
\hline T. paracetamol with cabbage & Decrease effectiveness of the drug. & PK & Moderate & $22(7.91)$ \\
\hline T. ciprofloxacin with tea/coffee (caffeine) & $\begin{array}{l}\text { Increased caffeine concentrations and } \\
\text { enhanced CNS stimulation }\end{array}$ & PK & Moderate & $68(24.46)$ \\
\hline T. ciprofloxacin with milk/curd & Decreased drug concentration & PK & Moderate & $65(23.38)$ \\
\hline
\end{tabular}

DFIs: Drug-food interaction

Table 10: Distribution of potential drug-disease interactions in cardiology

\begin{tabular}{|c|c|c|c|}
\hline Drug-disease & Interactive effect & Severity & Frequency $n=289(\%)$ \\
\hline T. ISDN with MI & Systemic hypotension and tachycardia & Major & $42(14.53 \%)$ \\
\hline $\begin{array}{l}\text { Injection furosemide with diabetes } \\
\text { mellitus }\end{array}$ & $\begin{array}{l}\text { Latent diabetes may become overt: Insulin requirements in } \\
\text { established diabetes may increase: Stop furosemide before a } \\
\text { glucose tolerance test }\end{array}$ & Moderate & $56(19.37)$ \\
\hline T. atenolol with DM & $\begin{array}{l}\text { Inhibit catecholamine-mediated glycogenolysis, thereby } \\
\text { potentiating insulin-induced hypoglycemia and delaying the } \\
\text { recovery of normal blood glucose levels }\end{array}$ & Major & $24(8.30)$ \\
\hline T. amlodipine with CAD & Unknown mechanism & Major & $18(6.22)$ \\
\hline
\end{tabular}

ISDN: Isosorbide dinitrate, MI: Myocardial infarction, DM: Diabetes mellitus, CHF: Congested heart failure, CAD: Coronary artery diseases

Table 11: Distribution of potential drug-disease interactions in pulmonology

\begin{tabular}{|c|c|c|c|}
\hline Drug-disease & Interactive effect & Severity & Frequency $n=138(\%)$ \\
\hline T. diazepam with COPD & Risk of respiratory depression & Moderate & $76(55.07)$ \\
\hline T. chlorpheniramine with COPD & $\begin{array}{l}\text { Reduce the volume and cause thickening of bronchial } \\
\text { secretions, resulting in obstruction of the respiratory tract }\end{array}$ & Moderate & $62(44.93)$ \\
\hline
\end{tabular}

COPD: Chronic obstructive pulmonary diseases

\section{CONCLUSION}

This study concluded that the overall incidence of the pDDIs was very high in cardiology when compared to pulmonology department. It was found that the incidence of pDDIs was associated with older age, male gender, number of medication given, and increased length of hospital stays. To reduce pDDIs, the number of medications for the patients need to properly controlled and it is recommended to eliminate all medications without therapeutic benefit, the goal, and indication. All potential DDIs are not equally harmful; therefore, identification of the level of each potential DDIs is integral to assess the clinical importance and appropriate management. Food-drug interactions can produce negative effects on the safety and efficacy of drug therapy as well as nutritional status of patients. Often, such interactions can be avoided by taking $1 \mathrm{~h}$ before or $2 \mathrm{~h}$ after eating. Therefore, providing information regarding the different food and drug interactions will help the physicians to prescribe drugs cautiously with only suitable food supplement to get maximum benefit for the patient. Our study reports several examples of interactions between drugs and diseases. Guideline developers could consider a more systematic approach regarding the potential for drug-disease interactions, based on epidemiological knowledge of the commodities of people with the disease, the guideline is focused on and should particularly consider whether cardiovascular diseases are common in the target population. Knowledge of such predictable or possible interactions is necessary for their timely detection and prevention of associated morbidity.

Pharmacists must take responsibility for observing for drug interactions and informing the doctor and the patient about potential issues. With their point-by-point information about drugs, pharmacists have the capacity to relate unforeseen side effects experienced by patients inconceivable adverse effects of their drug therapy. 


\section{AUTHORS' CONTRIBUTION}

All the authors have contributed equally.

\section{CONFLICTS OF INTEREST}

All authors have no conflicts of interest to declare.

\section{REFERENCES}

1. Mirosevic SN, Macolic SV, Mukalo I, Krnic D, Bozina N, Tomic S. Adverse drug reactions caused by drug-drug interactions reported to croatian agency for medicinal products and medical devices: A retrospective observational study. Croat Med J 2011;52:604-14.

2. Becker ML, Kallewaard M, Caspers PW, Visser LE, Leufkens HG, Stricker BH. Hospitalization and emergency department visits due to drug-drug interactions: A literature review. Pharmacoepidemiol Drug Saf 2007; 16:641-51.

3. Secoli SR, Figueras A, Lebrao M, Dias D, Santos J. Risk of potential drug-drug interactions among Brazilian elderly. Drugs Aging 2010;27:759-70.

4. Ismail M, Iqbal Z, Khattak MB, Javaid A, Khan TM. Prevalence, types and predictors of potential drug-drug interactions in Pulmonology ward of a tertiary care hospital. Afr J Pharm Pharmacol 2011;5:1303-9.

5. Yanti E, Kristin E, Yasmina A. Potential drug interactions in hypertensive patients in Liwa district hospital, Lampung Barat, Indonesia. Int J Pharm Pharm Sci 2017;9:134-8.

6. Hines LE, Murphy JE. Potentially harmful drug-drug interactions in the elderly: A review. Am J Geriatr Pharmacother 2011;9:364-77.

7. Kumar M, Dahiya V, Mishra S, Sharma D, Mishra N. Cardiovascular disease prevalence and drug utilization patterns at a tertiary care hospital in northeastern India. Int J Pharm Pharm Sci 2016;8:116-9.

8. Murtaza G, Khan MY, Azhar S, Khan SA, Khan TM. Assessment of potential drug-drug interactions and its associated factors in the hospitalized cardiac patients. Saudi Pharm J 2015;43:281-67.

9. Chelkebaa L, Alemsegedc F, Bedadaa W. Assessment of potential drug-drug interactions among outpatients receiving cardiovascular medications at Jimma University specialized hospital, South West Ethiopia. Int J Basic Clin Pharmacol 2013;2:144-52.
10. Fita R, Nurrochmah H, Wasilah R, Syed A. Potentiality of drug-drug interactions in hospitalized geriatric patients in a private hospital, Yogyakarta, Indonesia. Asian J Pharm Clin Res 2010;3:191-4.

11. Lubinga SJ, Uwiduhaye E. Potential drug-drug interactions on inpatient medication prescriptions at Mbarara regional referral Hospital (MRRH) in western Uganda: Prevalence, clinical importance and associated factors. Afr Health Sci 2011;11:499-7.

12. de Andrade TN, Silvestre CC, Cunha LC, de Silva DT, Marques TC, Oliveira-Filho AD, et al. Pharmaceutical intervention, assessment in the identification and management of drug interactions in an intensive care unit. J Appl Pharm Sci 2015;5:13-8.

13. Mannesse CK, Derkx FH, de Ridder MA, Man in 't Veld AJ, van der Cammen TJ. Contribution of adverse drug reactions to hospital admission of older patients. Age Ageing 2000;29:35-9.

14. Doan J, Zakrzewski-Jakubiak H, Roy J, Turgeon J. Prevalence and risk of potential cytochrome P450-mediated drug-drug interactions in older hospitalized patients with polypharmacy. Ann Pharmacother 2013;47:324-32.

15. Fokter N, Mozina M, Brvar M. Potential drug-drug interactions and admissions due to drug-drug interactions in patients treated in medical departments. Wien Klin Wochenschr 2010;122:81-8.

16. Chavda N, Solanky P, Baria H, Naik R, Bharti K. Study of potential drug-drug interaction between prescribed drugs in patients attending outpatient department of medicine at tertiary-care hospital in south Gujarat region. Natl J Physiol Pharm Pharmacol 2015:5:236-42.

17. Vonbach P, Dubied A, Krahenbuhl S, Beer JH. Prevalence of drug drug interactions at hospital entry and during hospital stays of patients in internal medicine. Eur J Intern Med 2008;19:413-20.

18. Aparasu R, Baer R. Clinically important potential drug-drug interactions in outpatient settings. Res Social Adm Pharm 2007;3:426-37.

19. AvoidFood andDrug Interaction;2010. Available from: http://www.fda.gov/ downloads/drugs/resourcesforyou/consumers/buyingusingmedicinesafely/ ensuringsafeuseofmedicine/generaluseofmedicine/ucm229033.pdf. [Last assessed on 2016 Jun 25].

20. Tse FL, Valia KH, Szeto DW, Raimondo TJ, Koplowitz B. Effect of caffeine on circulating theophylline levels. J Pharm Sci 1981;70:395-9.

21. Dimitriadis G, Tegos C, Golfinopoulou L, Roboti C, Raptis S. Furosemide-induced hyperglycemia: The implication of glycolytic kinases. Horm Metab Res 1993;25:557-9. 